\title{
Detection of Campylobacter pylori DNA by hybridisation with non-radioactive probes in comparison with a ${ }^{32} \mathrm{P}$-labelled probe
}

\author{
B. L. WETHERALL, P. J. McDONALD and A. M. JOHNSON
}

Department of Clinical Microbiology, Flinders Medical Centre, Bedford Park, South Australia 5042, Australia

\begin{abstract}
Summary. A dot-blot hybridisation assay for the detection of Campylobacter pylori was used to compare a ${ }^{32} \mathrm{P}$-labelled probe with two biotinylated probes and a sulphonated probe. The minimum amount of pure $C$. pylori DNA that could be detected by the ${ }^{32} \mathrm{P}$-labelled probe was $100 \mathrm{pg}$, which corresponded to $5 \times 10^{4}$ bacteria. A biotin-labelled DNA (biotin-DNA) probe together with the BluGene ${ }^{\mathrm{TM}}$ detection system produced by Bethesda Research Laboratories (BRL), and a sulphonated probe and Chemiprobe ${ }^{\mathrm{TM}}$ detection system (Orgenics) gave similar levels of sensitivity; nylon membranes could be used with both these non-radioactive detection systems. However, a photobiotin-labelled DNA (photobiotin-DNA) probe and detection system produced by Biotechnology Research Enterprises S.A. (BRESA) gave optimum results only with nitrocellulose membranes, and was quantitatively 100 times less sensitive than the other types of probe. The detection systems for the biotinDNA and photobiotin-DNA probes produced non-specific reactions with crude bacterial blots of heterologous organisms; these non-specific reactions could be removed by treating the dot blots with proteinase $K$, but not by treatment with RNAase. The sulphonated probe and detection system did not give any reaction with heterologous organism blots.
\end{abstract}

\section{Introduction}

DNA probes are proving to be of increasing value in the clinical laboratory. Practical uses include the rapid and definitive detection of specific gene sequences in isolates (Moseley et al., 1980; Levine et al., 1987) or clinical specimens (Hyypia, 1985; Roberts et al., 1985), a guide in the identification of organisms which are otherwise difficult to identify (Roberts et al., 1987a) and the epidemiological study of organisms containing plasmidmediated antibiotic resistance (Ouellette et al., 1987). Most of the probes that have been described are labelled with ${ }^{32} \mathrm{P}$. However, these have the inherent problems of potential hazard to the user, short half-lives and the requirement for specially equipped laboratories. Several non-radioactive methods for labelling nucleic acids have been described recently. Biotinylated probes have been prepared by labelling nucleotides with biotin by nick-translation (Langer et al., 1981), and also by linking photobiotin, a photoactivatable analogue of biotin, to nucleic acids (Forster et al., 1985).

Received 13 Oct. 1987; accepted 7 Dec. 1987.
With these probes, target DNA sequences have been detected by the reaction of biotin with streptavidin or avidin enzyme complexes, and a chromogenic substrate (Leary et al., 1983; Forster et al., 1985). Another approach has been to sulphonate DNA (Verdlov et al., 1974) and to detect hybridised probes with monoclonal antibody to the modified DNA, enzyme-labelled anti-species immunoglobulin and a chromogenic substrate (Hyman et al., 1987). Non-isotopic probes have the advantages of long shelf life, safe manipulation for users, and suitability for use in the clinical laboratory.

Campylobacter pylori is a recently described organism that has been associated with active chronic gastritis, gastric ulcer, duodenal ulcer, and non-ulcer dyspepsia (Marshall and Warren, 1984; Buck et al., 1986; Wyatt et al., 1986). The role of this organism in the pathogenesis of these conditions is not clear; and it has not been isolated from any other body sites of man, nor from the environment. This may be due partially to the organism's fastidious growth requirements : even in specimens of gastric antrum, C. pylori may not be 
isolated because of poor technique, either during the collection of the biopsy specimen or later in the laboratory (Goodwin et al., 1986). While the rapid urease test for the direct detection of $C$. pylori in biopsy specimens appears to give satisfactory results in the initial screening of patients, negative results have been found when the culture was positive (Borromeo et al., 1987); furthermore, the urease test may not be reliable for the testing of patients after treatment.

The aims of this study were to compare $C$. pylori ${ }^{32}$ P-labelled genomic DNA probes with three nonradioactive probes, to test the compatibility of the latter probes with nylon membranes, and to determine the specificity of non-isotopic probes in reactions with crude bacterial dot blots.

\section{Materials and methods}

\section{Bacterial strains}

The $C$. pylori strain used for the preparation of probes was a clinical isolate obtained from a gastric biopsy. The tissue was minced in normal saline and inoculated on to a selective medium consisting of Brucella Agar (BBL Microbiological Systems, Cockeysville, MD, USA), defibrinated sheep blood $10 \%$, vitox $2 \%$, and Skirrow selective antibiotics (Oxoid). The plates were incubated at $35^{\circ} \mathrm{C}$ in microaerophilic conditions provided by a Campy Pak envelope (BBL) in a GasPak jar (BBL) without catalyst. Other organisms used were reference cultures: C. pylori NCTC 11637, gastric campylobacterlike organism type 2 (GCLO2) NCTC 11847, C. jejuni NCTC 11351, C. fetus ss. fetus NCTC 10842 and Escherichia coli ATCC 25922. For subcultures, the Campylobacter strains were grown on chocolate agar plates in microaerophilic conditions at $35^{\circ} \mathrm{C}$ for 2-4 days.

\section{Preparation of DNA}

The clinical isolate of $C$. pylori was grown on 50 chocolate agar plates for 4 days, and the growth was harvested in $40 \mathrm{ml}$ of phosphate buffered saline (PBS), $p H$ 7.2. Debris was removed by centrifuging the suspension at $70 \mathrm{~g}$ for $5 \mathrm{~min}$. The supernatant fluid was centrifuged at $3300 \mathrm{~g}$ for $10 \mathrm{~min}$, and the pellet was suspended in $20 \mathrm{ml}$ of $10 \mathrm{mM}$ Tris- $\mathrm{HCl}$ buffer, $p \mathrm{H} 8.5$, and $10 \mathrm{~mm}$ sodium EDTA. The suspension was centrifuged again and the pellet resuspended in $5 \mathrm{ml}$ of the same buffer. DNA was purified as described by Langenberg et al. (1986), but with several modifications. Lysozyme (Egg white grade I; Sigma Chemical Co., St Louis, MO, USA) was added to give a final concentration of $1 \mathrm{mg} / \mathrm{ml}$, and the solution was incubated at $37^{\circ} \mathrm{C}$ for $30 \mathrm{~min}$. The bacteria were lysed with $1 \%$ sodium dodecylsulphate (SDS). The lysate was incubated with RNAase A (bovine pancreas type XII-A; Sigma) at a final concentration of $200 \mu \mathrm{g} / \mathrm{ml}$ at $37^{\circ} \mathrm{C}$ for $60 \mathrm{~min}$, then for $3 \mathrm{~h}$ at $50^{\circ} \mathrm{C}$ in the presence of proteinase $\mathrm{K} 200 \mu \mathrm{g} / \mathrm{ml}$
(Boehringer Mannheim GmbH Biochemical, Mannheim, FRG). Sodium perchlorate was added to the lysate to a final concentration of $1 \mathrm{M}$, and the DNA was extracted with an equal volume of a mixture of phenolchloroform-isoamylalcohol $(25: 24: 1 \mathrm{v}: \mathrm{v}: \mathrm{v})$. Three further extractions were done with this mixture. After another two extractions with chloroform, the DNA was precipitated with ethanol and redissolved in $10 \mathrm{~mm}$ Tris$\mathrm{HCl}, 1 \mathrm{mM}$ sodium EDTA, $p \mathrm{H} \mathrm{7.5}$ (TE). The DNA was considered sufficiently pure and free of contaminating proteins because the absorbance ratios $230 / 260$ and $280 /$ 260 were 0.44 and 0.49 (Owen and Leaper, 1981). The DNA concentration was determined by the diphenylamine assay, as described by Giles and Meyers (1965).

\section{Labelling of DNA probes}

Genomic DNA probes were labelled with $\left[\alpha^{32} \mathrm{P}\right] \mathrm{dCTP}$ (Biotechnology Research Enterprises S.A. [BRESA], Adelaide, South Australia) by use of a nick translation kit (Bethesda Research Laboratories [BRL], Gaithersburg, MD, USA) according to the manufacturer's protocol; after labelling, unincorporated nucleotides were removed by Sephadex G-50 chromatography, with $100 \mathrm{~mm} \mathrm{NaCl}, 20 \mathrm{~mm}$ Tris- $\mathrm{HCl}, 10 \mathrm{~mm}$ sodium EDTA buffer, $p \mathrm{H} 7 \cdot 5$, used for washing. Biotin-labelled probes were prepared by incorporating Biotin-11-dUTP (BRL) into DNA by use of the BRL nick translation kit; unincorporated nucleotides were removed by ethanol precipitation. For labelling with photobiotin, DNA was prepared in distilled water; photobiotin acetate (BRESA) was then incorporated as recommended by the manufacturer and as described by Forster et al. (1985). Sulphonated DNA probes were prepared by inserting an antigenic sulphone group into cytosine moieties of denatured DNA (Chemiprobe kit; Orgenics Ltd, Yavne, Israel).

\section{Preparation of target $D N A$}

Blots for sensitivity. Serial dilutions of homologous purified DNA were made in TE. DNA was denatured by heating to $100^{\circ} \mathrm{C}$ for $10 \mathrm{~min}$, and $10 \mu \mathrm{l}$-amounts were dotted on to nitrocellulose (NC) (Bio-Rad Laboratories, Richmond, CA, USA) and charged nylon membranes (Pall Biodyne A; Pall Ultrafine Filtration Corp., Glen Cove, NY, USA) by use of the Bio-Dot microfiltration apparatus (Bio-Rad). NC membranes were presoaked in $20 \times \operatorname{SSC}(1 \times \mathrm{SSC}$ is $0.15 \mathrm{M} \mathrm{NaCl}$ plus $15 \mathrm{~mm}$ sodium citrate $p \mathrm{H} \mathrm{7.0)}$ and nylon membranes in $5 \times$ SSC. All dot blots on NC were washed with $20 \times$ SSC, and those on nylon were washed with $5 \times$ SSC. The filters were dried in air and baked for $2 \mathrm{~h}$ in vacuo at $80^{\circ} \mathrm{C}$.

Blots were also prepared to determine the sensitivity for whole bacteria. The homologous strain of $C$. pylori was grown on chocolate agar, and the colonies were suspended in Brain Heart Infusion Broth (Oxoid) containing vitox (Oxoid) $1 \%$, glucose $1 \%$, yeast extract $0.25 \%$ and inactivated horse serum $10 \%$ (HSB) to give the density of a McFarland standard no. 7. The number of viable organisms was determined by diluting the 
suspension and spreading portions on chocolate agar plates, which were incubated for 4 days in microaerophilic conditions. The total number of organisms was determined in a Helber counting chamber. Serial dilutions of the suspension were made in HSB, and $2 \cdot 5-\mu l$ amounts were dotted on to a nylon membrane with the Bio-Dot apparatus. After drying in air for $30 \mathrm{~min}$, the membrane was treated sequentially with $0.5 \mathrm{~N} \mathrm{NaOH}, 1.5 \mathrm{M} \mathrm{NaCl}$; proteinase $\mathrm{K}$; and $3 \mathrm{M}$ Tris $-\mathrm{HCl} \mathrm{pH} 8.0$ as described below.

Preparation of crude bacterial blots. Organisms were grown on chocolate agar (Campylobacter spp.) or blood agar (E. coli), and the growth from each was harvested in PBS to a density of a McFarland standard no. 7. The concentrations were checked in a Helber counting chamber, and adjusted if necessary to give a uniform count of $2 \times 10^{9}$ bacteria $/ \mathrm{ml}$. The suspensions were spotted on to nylon membranes with the Bio-Dot apparatus, in $2 \cdot 5-\mu 1$ volumes, to give a concentration of $5 \times 10^{6}$ bacteria/dot. Three membranes, each containing the series of different species were prepared for each probe. Bacteria were lysed and their DNA denatured by treating the membranes in three different ways. All membranes were initially floated on the surface of a hot $\left(60^{\circ} \mathrm{C}\right)$ solution containing $0.5 \mathrm{~N} \mathrm{NaOH}$ and $1.5 \mathrm{M} \mathrm{NaCl}$ for $30 \mathrm{~s}$, removed, and incubated in the same solution at $22^{\circ} \mathrm{C}$ for $10 \mathrm{~min}$ (Roberts et al., 1985). The membranes were then transferred to a solution of $3 \mathrm{M} \mathrm{Tris}-\mathrm{HCl}, p \mathrm{H}$ 8.0 , and incubated at room temperature for $10 \mathrm{~min}$ (Wirth and Pratt, 1982). After drying in air for $15 \mathrm{~min}$, one membrane was baked for $1 \mathrm{~h}$ in vacuo at $80^{\circ} \mathrm{C}$. One membrane was treated with a solution of RNAase A (Sigma) at $50 \mu \mathrm{g} / \mathrm{ml}$ in $3 \mathrm{M}$ Tris- $\mathrm{HCl}, p \mathrm{H} 8 \cdot 0$, for $30 \mathrm{~min}$ at $37^{\circ} \mathrm{C}$, while the remaining membrane was treated with a solution of proteinase $\mathrm{K}$ (Boehringer Mannheim) at $200 \mu \mathrm{g} / \mathrm{ml}$ in $3 \mathrm{M} \mathrm{Tris}-\mathrm{HCl}, \mathrm{pH} 8.0$, for $30 \mathrm{~min}$ at $37^{\circ} \mathrm{C}$. The latter two membranes were then dried in air for 15 min, treated with $3 \mathrm{M}$ Tris- $\mathrm{HCl}, p \mathrm{H} 8 \cdot 0$, for $10 \mathrm{~min}$ at $22^{\circ} \mathrm{C}$, and baked for $\mathrm{l} h$ in vacuo at $80^{\circ} \mathrm{C}$.

\section{Hybridisation and detection conditions}

${ }^{32}$ P-labelled probes. Membranes were prehybridised for $6 \mathrm{~h}$ at $65^{\circ} \mathrm{C}$ in hybridisation solution containing $6 \times$ SCC, $5 \times$ Denhardt solution $(1 \times$ Denhardt solution is polyvinylpyrrolidone $0.02 \%$, Ficoll $0.02 \%$, and bovine serum albumin fraction $\mathrm{V} 0.02 \%), 20 \mathrm{mM} \mathrm{NaPO}(p \mathrm{H}$ $6.5)$, SDS $0.1 \%$, dextran sulphate $10 \%$, and denatured salmon testes DNA $10 \mu \mathrm{g} / \mathrm{ml}$. The probe was denatured by heating at $100^{\circ} \mathrm{C}$ for $10 \mathrm{~min}$, and added to fresh hybridisation solution. The radioactivity counts of all probes were $(6-8) \times 10^{6} \mathrm{cpm} / \mathrm{ml}$ during hybridisation. After hybridisation for $16 \mathrm{~h}$ at $65^{\circ} \mathrm{C}$, the membranes were washed at $50^{\circ} \mathrm{C}$ for $3 \mathrm{~h}$ in four changes of $0.2 \times \mathrm{SSC}$ containing SDS $0.1 \%$ dried in air and exposed to $\mathrm{X}$-ray film between intensifying screens at $-70^{\circ} \mathrm{C}$ for $20 \mathrm{~h}$. The film was developed with an X-ray film developer, and examined for specific hybridisation to target DNA.

Biotinylated probes. Hybridisation with biotin-DNA probes was done according to the manufacturers' protocol for the BluGene ${ }^{T M}$ non-radioactive nucleic acid detection system (BRL), but with several modifications: (a) formamide was omitted from the prehybridisation and hybridisation solutions; (b) to compensate, the prehybridisation temperature was increased to $65^{\circ} \mathrm{C}$, and the hybridisation temperature to $61^{\circ} \mathrm{C}$; (c) the hybridisation conditions recommended for nylon membranes were used for both NC and nylon membranes; (d) probes were denatured at $100^{\circ} \mathrm{C}$ for $10 \mathrm{~min}$. The hybridisation temperature of $61^{\circ} \mathrm{C}$ was used to allow for the slightly lower melting temperature of biotin-labelled DNA duplexes (Leary et al., 1983), while the other changes were made for practical reasons and to achieve maximum signal-to-noise ratios. All probes were used at a concentration of $200 \mathrm{ng} / \mathrm{ml}$, and hybridisation was for $16 \mathrm{~h}$. Posthybridisation washes of both NC and nylon membranes were done by the method for nylon membranes. Hybridisation reactions were detected and visualised with a streptavidin alkaline phosphatase (SA-AP) conjugate and a chromogenic substrate containing nitroblue tetrazolium and 5-bromo-4-chloro-3-indolyl phosphate (NBT/BCIP) supplied with the kit. The staining reaction was stopped after $4 \mathrm{~h}$, to ensure maximum colour development.

Hybridisation with photobiotin-DNA probes was done as described for biotin-DNA probes, the temperature of $61^{\circ} \mathrm{C}$ being used for hybridisation. The probes were used at a final concentration of $25 \mathrm{ng} / \mathrm{ml}$ in the hybridisation solution. Photobiotinylated DNA, hybridised to target DNA, was detected with an avidin alkaline phosphatase (A-AP) conjugate and substrate solution NBT/BCIP, supplied with the BRESA kit. Colour development was stopped after $4 \mathrm{~h}$.

Sulphonated probes. Membranes were prehybridised for $4 \mathrm{~h}$ at $65^{\circ} \mathrm{C}$ in hybridisation solution containing $1 \mathrm{M}$ $\mathrm{NaCl}$, SDS $1 \%$, dextran sulphate $10 \%$ and denatured salmon testes DNA $250 \mu \mathrm{g} / \mathrm{ml}$. The probe was denatured by heating at $100^{\circ} \mathrm{C}$ for $10 \mathrm{~min}$, and added to fresh hybridisation solution (without salmon testes DNA). The concentration of the probe in the hybridisation buffer was $1 \mu \mathrm{g} / \mathrm{ml}$, and hybridisation was for $16 \mathrm{~h}$ at $65^{\circ} \mathrm{C}$. Posthybridisation washes consisted of two washes for 10 min each at $22^{\circ} \mathrm{C}$ in $2 \times \mathrm{SSC}$, followed by a 30 -min wash at $65^{\circ} \mathrm{C}$ in $2 \times \mathrm{SSC}$ containing SDS $1 \%$ and a $30-\mathrm{min}$ wash at $65^{\circ} \mathrm{C}$ in $0.1 \times \mathrm{SSC}$ containing SDS $1 \%$. Immunological visualisation of the hybridised probe was done with reagents supplied in the Chemiprobe ${ }^{\mathrm{TM}}$ kit. Briefly, membranes were treated with a blocking solution containing skimmed milk $25 \%$ and heparin $3.5 \mathrm{mg} / \mathrm{ml}$. They were then incubated with a monoclonal antibody to modified DNA. After washing, the membranes were incubated with an anti-species immunoglobulin alkaline phosphatase conjugate. After a further series of washes, the membranes were exposed to substrate solution NBT/ BCIP at $37^{\circ} \mathrm{C}$ for $1 \mathrm{~h}$.

\section{Results}

\section{Sensitivity of probes}

The sensitivity of $C$. pylori genomic DNA probes 
was determined by hybridisation reactions with serial concentrations of homologous purified DNA, immobilised on nylon and NC membranes. For nylon membranes the lowest detectable amounts of DNA were $100 \mathrm{pg}$ with the ${ }^{32} \mathrm{P}$, biotin-DNA, and sulphonated probes, and $10 \mathrm{ng}$ with the photobiotin-DNA probe (fig. 1). There was no difference in the limit of detection when NC membranes were used, and no difference in the intensity of background reactions, apart from that found with the photobiotin detection system. This probe gave markedly higher backgrounds whenever nylon membranes were used, and although the results were the same as on $\mathrm{NC}$, the signal-to-noise ratio was considerably decreased.

To correlate these sensitivity results for purified DNA with the number of bacteria detectable, the different types of probe were hybridised to dot blots of denatured and fixed homologous cells. Initially both nylon and NC membranes were used, but the latter became unacceptably brittle and difficult to handle after the denaturing treatment. The detection sensitivity, with dot blots on nylon membranes, was $5 \times 10^{4}$ bacteria for the ${ }^{32} \mathrm{P}$, biotin-DNA and sulphonated probes (data not shown). The lowest concentration detected by the photobiotin-DNA probe was $5 \times 10^{6}$ bacteria, consistent with the 100 fold lower sensitivity obtained with pure DNA.

\section{Crude bacterial blots}

The extent of cross-hybridisation with heterologous bacteria was determined by preparing dot

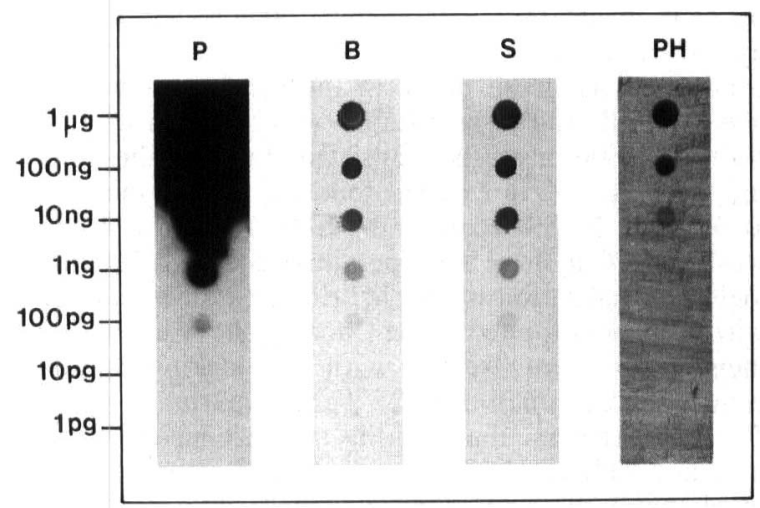

Fig. 1. The sensitivity of dot-blot hybridisation assays of purified C. pylori DNA on nylon membranes with various types of probes: $\mathbf{P},{ }^{32} \mathbf{P}$; B, biotin-DNA ; S, sulphonated-DNA; PH, photobiotin-DNA. Seven 10-fold dilutions of pure DNA were filtered on to membranes for each probe $(1 \mu \mathrm{g}, 100 \mathrm{ng}, 10 \mathrm{ng}$, $1 \mathrm{ng}, 100 \mathrm{pg}, 10 \mathrm{pg}, 1 \mathrm{pg}$ ). The lowest concentration detected by the ${ }^{32} \mathrm{P}$, biotin-DNA and sulphonated-DNA probes was $100 \mathrm{pg}$ (very faint for biotin-DNA), whereas the end-point for the photobiotin-DNA probe was $10 \mathrm{ng}$. blots from whole bacterial suspensions, without isolating the DNA of each organism. This method was used by Totten et al. (1985) to screen campylobacter-like organisms (CLOs) for homology, and for the rapid differentiation of CLO strains. We also used this format to assess the performance of the various probes after treating the membranes with a proteolytic enzyme or RNAase.

The intensity of the reactions was strongest with the homologous strains of $C$. pylori (fig. 2). For the ${ }^{32} \mathrm{P}$ and sulphonated probes these homologous reactions could be differentiated from the reactions with other Campylobacter spp. and E. coli, irrespective of the membrane treatment. However, the biotin and photobiotin detection systems gave positive reactions with all the bacterial dot blots, when the membranes had been treated with alkali or alkali and RNAase. These non-specific reactions were eliminated by treatment of the membranes with proteinase $K$. The results obtained with the photobiotin-DNA probe were unsuitable for illustration in fig. 2, because of excessive background staining of the nylon membrane.

\section{Discussion}

In this study we used DNA from $C$. pylori to compare three non-radioactive probes with a ${ }^{32} \mathrm{P}$ labelled probe, and to determine whether nylon membranes could be used with the former probes. An important pre-requisite for the use of gene probes in clinical laboratories is a stable, safe, flexible and hardy hybridisation and detection system. We have found that $\mathrm{NC}$ membranes become extremely brittle during the preparation of dot blots, particularly after treatment with denaturing solutions. With the methods used here, a nylon membrane was found to be suitable for use with two non-radioactive detection systems: a biotinylated probe with the BluGene ${ }^{\mathrm{TM}}$ (BRL) detection system, and a sulphonated probe with the Chemiprobe $^{\mathrm{TM}}$ (Orgenics) kit. With these probes, the sensitivity results obtained with nylon membranes were the same as the results with NC membranes. In addition the intensity of the background staining of the two types of membrane was similar. In contrast, Zwadyk et al. (1986) reported that a detection system for biotinylated probes (BRL) could not be used with a charged nylon membrane, Zeta-Probe (Bio-Rad), although another biotin detection system (Enzo Biochem) gave acceptable results. These variations can probably be attributed to differences in the brands of nylon membrane used, and the particular 


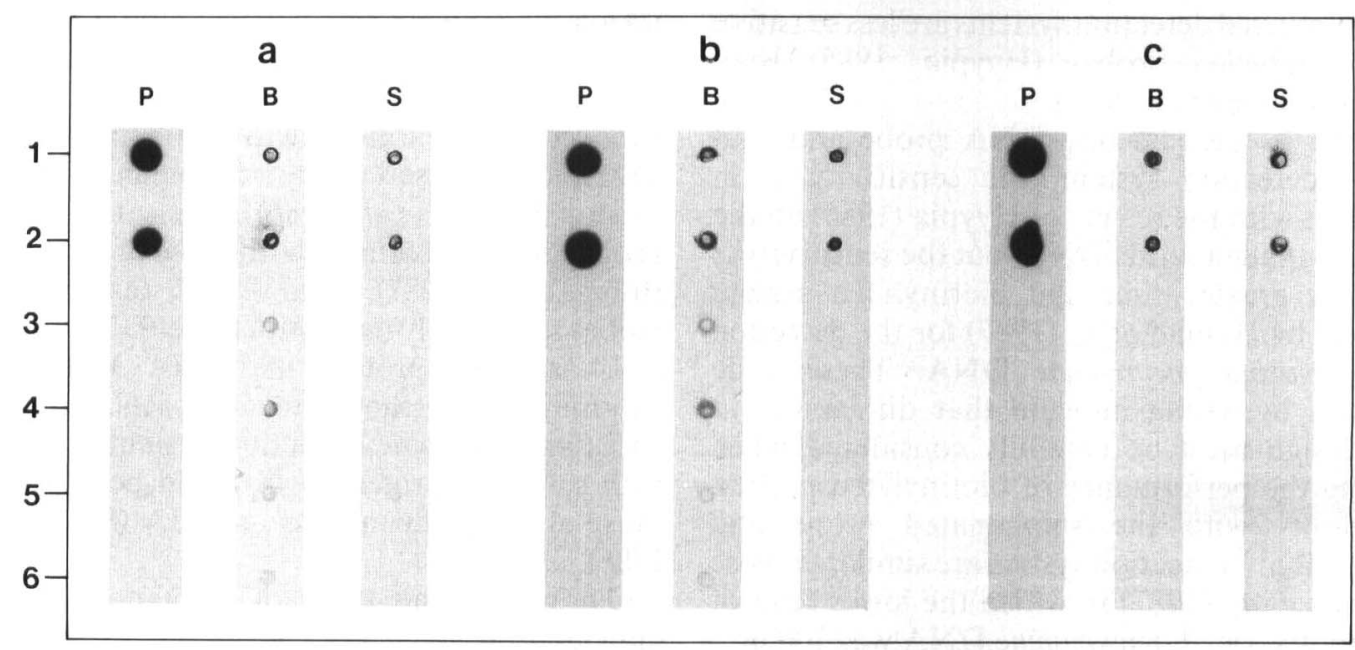

Fig. 2. Dot-blot hybridisation tests showing the specificity of the probes and non-specific background reactions. Bacterial suspensions of (1) C. pylori homologous to probe, (2) C.pylori NCTC 11637, (3) GCLO2 NCTC 11847, (4) C. jejuni NCTC 11351, (5) C. fetus ss. fetus NCTC 10842, (6) E. coli ATCC 25922, were spotted on to nylon membranes and treated with (a) $0.5 \mathrm{~N} \mathrm{NaOH}, 1 \cdot 5 \mathrm{M} \mathrm{NaCl}$, (b) $0.5 \mathrm{~N} \mathrm{NaOH}, 1.5 \mathrm{M} \mathrm{NaCl}$ and $\mathrm{RNAase}$, (c) $0.5 \mathrm{~N} \mathrm{NaOH}, 1.5 \mathrm{M} \mathrm{NaCl}$ and proteinase $\mathrm{K}$. Probes and detection systems for the three lanes were: $\mathbf{P},{ }^{32} \mathbf{P} ; \mathbf{B}$, biotin-DNA; $\mathbf{S}$, sulphonated-DNA.

detection system. Thus, before a biotinylated detection method is introduced, the performance characteristics of the probe with various nylon membranes should be established.

Few reports are available on the use of a sulphonated probe and the Chemiprobe ${ }^{\mathrm{TM}}$ detection system. Hyman et al. (1987), using a sulphonated probe and NC membranes, reported good results for the detection of Mycoplasma DNA. Our results indicate that this non-radioactive detection system is readily adaptable to nylon membranes.

The photobiotin-DNA probe and detection system gave unacceptably high backgrounds when tested with the nylon membrane used in this study. This occurred despite the use of conditions which are known to reduce background reactions. Two high stringency washes were included with the posthybridisation washing conditions, and the blocking procedure for nylon membranes as recommended by the manufacturer was used.

Although the photobiotin probe gave low signalto-noise ratios on nylon membranes, the sensitivity was the same as on NC membranes. The smallest amount of purified $C$. pylori DNA and cells spotted on either type of membrane that could be detected was 100 -fold greater than that obtained with the ${ }^{32} \mathrm{P}$, biotin-DNA and sulphonated probes. This was not due to a low level of incorporation of photobiotin acetate into the DNA, or to an inefficient colourimetric detection system, because when the photobiotin probe was spotted on to NC membranes and tested with the colourimetric detection procedure, the limit of detection sensitivity was $2 \mathrm{pg}$ of probe (data not shown). This is similar to the results obtained in a study by Forster et al. (1985) using phage M13 DNA probes, where $4 \mathrm{pg}$ of bio-M13 DNA was detected. They also reported that the bio-M13 DNA probe could detect $0.5 \mathrm{pg}$ of target DNA in a dot-blot hybridisation procedure. The poor sensitivity with the $C$. pylori photobiotin-DNA probe, found here, may be due to the nature of the probe. The $C$. pylori probe was made with genomic DNA, whereas the bio-M13 probe was prepared from single-stranded bacteriophage DNA. Khan and Wright (1987) have also recently reported that photobiotin-labelled cDNA probes to flavivirus RNA were not as sensitive as ${ }^{32} \mathrm{P}$-labelled probes.

The sensitivity of the ${ }^{32} \mathrm{P}$-labelled probe for purified $C$. pylori DNA is in agreement with the results of others on the detection of Plasmodium falciparum DNA by genomic probes (McLaughlin et al., 1987) and the detection of Mycobacterium tuberculosis and Myco. avium complex (Roberts et $a l ., 1987 b$ ). Likewise, the sensitivity for bacterial dot blots is similar to that in a study on the identification of Mobiluncus (Roberts et al., 1984) which required a minimum of $10^{4}$ organisms/spot to give visible hybridisation reactions.

In our study, the limits of detectable target sequence of the biotin-DNA probe and the sulphonated probe were equal to that of the ${ }^{32} \mathrm{P}$-labelled probe for both purified $C$. pylori DNA and crude bacterial dot blots. In contrast, others have found 
that biotinylated detection systems are less sensitive than ${ }^{32}$ P-labelled probes (Hyypia, 1985; Bialkowska-Hobrzanska, 1987).

For the C. pylori biotin-DNA probe and BluGene $^{\mathrm{TM}}$ detection system, the sensitivity is in agreement with the results of Hyypia (1985) on the detection of adenovirus DNA, but the sensitivity is somewhat greater than the biotinylated system described by Hyman et al. (1987) for the detection of Mycoplasma pneumoniae DNA. These wide variations in results indicate that differences in study design must be carefully considered when assessing the performance of biotinylated probes. Our results with the sulphonated probe and Chemiprobe ${ }^{\mathrm{TM}}$ detection system are similar to those of Hyman et al. (1987) in which the lower limit of detectability for $M$. pneumoniae DNA was $100 \mathrm{pg}$.

DNA-DNA hybridisation with a dot-blot format and ${ }^{32} \mathrm{P}$-labelled probes has been found to be useful for the identification and differentiation of Campylobacter spp. (Totten et al., 1985; Tee et al., 1987) and Mobiluncus spp. (Roberts et al., 1984). However for practical clinical laboratory use, non-radioactive probes in conjunction with crude bacterial blots are desirable. Zwadyk et al. (1986) were unable to prevent non-specific reactions with crude bacterial lysates, when using a biotinylated system, despite extreme purification procedures. To a certain extent, our results concur with this observation in that non-specific reactions were found with heter-

\section{REFERENCES}

Bialkowska-Hobrzanska H 1987 Detection of enterotoxigenic Escherichia coli by dot blot hybridization with biotinylated DNA probes. Journal of Clinical Microbiology 25:338-343.

Borromeo M, Lambert J R, Pinkard K J 1987 Evaluation of "CLO"-test to detect Campylobacter pyloridis in gastric mucosa. Journal of Clinical Pathology 40:462-463.

Buck G E, Gourley W K, Lee W K, Subramanyam K, Latimer J M, DiNuzzo A R 1986 Relation of Campylobacter pyloridis to gastritis and peptic ulcer. Journal of Infectious Diseases 153:664-669.

Forster A C, McInnes J L, Skingle D C, Symons R H 1985 Nonradioactive hybridization probes prepared by the chemical labelling of DNA and RNA with a novel reagent, photobiotin. Nucleic Acids Research 13:745-761.

Giles K W, Meyers A 1965 An improved diphenylamine method for the estimation of deoxyribonucleic acid. Nature $206: 93$.

Goodwin C S, Armstrong J A, Marshall B J 1986 Campylobacter pyloridis, gastritis, and peptic ulceration. Journal of Clinical Pathology 39:353-365.

Hyman H C, Yogev D, Razin S 1987 DNA probes for detection and identification of Mycoplasma pneumoniae and $\mathrm{Myco}$ plasma genitalium. Journal of Clinical Microbiology 25 : 726 728.

Hyypia T 1985 Detection of adenovirus in nasopharyngeal specimens by radioactive and nonradioactive DNA probes. Journal of Clinical Microbiology 21 : 730-733. ologous organisms when both biotinylated detection systems were used. These could not be removed by treating the blots with RNAase, but were removed by treatment with proteinase $K$. The reason for the discrepancy between our results and those of Zwadyk et al. (1986) is unclear, particularly as ours are in agreement with those of BialkowskaHobrzanska (1987), who found that Bio-DNA probes specifically react with target DNA when the DNA is free of proteins and RNA. We found no requirement for the removal of RNA. If this is necessary for some detection systems, treatment with sufficient proteinase $K$ could be expected to cause also significant loss of RNA (Singer et al., 1986).

Our results and those of Hyman et al. (1987) indicate that non-specific reactions with cell components do not occur with sulphonated probes and the Chemiprobe ${ }^{\mathrm{TM}}$ detection system. Thus no treatment of crude bacterial blots is required. Although the detection and visualisation stages of the Chemiprobe ${ }^{\mathrm{TM}}$ system take longer to complete than biotinylated methods, sulphonated probes provide an attractive alternative to biotinylated probes. Further studies, particularly with clinical material, are required to establish the usefulness of sulphonated probes. A comparison of this type of probe with biotinylated probes in the examination of clinical material for $C$. pylori is presently being done in our laboratory.

Khan A M, Wright P J 1987 Detection of flavivirus RNA in infected cells using photobiotin-labelled hybridization probes. Journal of Virological Methods 15: 121-130.

Langenberg W, Rauws E A J, Widjojokusumo A, Tytgat G N J, Zanen H C 1986 Identification of Campylobacter pyloridis isolates by restriction endonuclease DNA analysis. Journal of Clinical Microbiology 24:414-417.

Langer P R, Waldrop A A, Ward D C 1981 Enzymatic synthesis of biotin-labelled polynucleotides: Novel nucleic acid affinity probes. Proceedings of the National Academy of Sciences of the USA 78:6633-6637.

Leary J J, Brigati D J, Ward D C 1983 Rapid and sensitive colorimetric method for visualizing biotin-labelled DNA probes hybridized to DNA or RNA immobilized on nitrocellulose: bio-blots. Proceedings of the National Academy of Sciences of the USA 80:4045-4049.

Levine M M et al. 1987 A DNA probe to identify enterohemorrhagic Escherichia coli of 0157:H7 and other serotypes that cause hemorrhagic colitis and hemolytic uremic syndrome. Journal of Infectious Diseases 156: 175-182.

Marshall B J, Warren J R 1984 Unidentified curved bacilli in the stomach of patients with gastritis and peptic ulceration. Lancet 1 : 1311-1315.

Moseley S L, Huq I, Alim A R M A, So M, Samadpour-Motalebi M, Falkow S 1980 Detection of enterotoxigenic Escherichia coli by DNA colony hybridization. Journal of Infectious Diseases 142:892-898.

McLaughlin G L, Collins W E, Campbell G H 1987 Comparison 
of genomic, plasmid, synthetic, and combined DNA probes for detecting Plasmodium falciparum DNA. Journal of Clinical Microbiology 25:791-795.

Ouellette M, Rossi J J, Bazin R, Roy P H 1987 Oligonucleotide probes for the detection of TEM-1 and TEM-2 betalactamase genes and their transposons. Canadian Journal of Microbiology 33:205-211.

Owen R J, Leaper S 1981 Base composition, size and nucleotide sequence similarities of genome deoxyribonucleic acids from species of the genus Campylobacter. FEMS Microbiology Letters 12:395-400.

Roberts M C, Hillier S L, Schoenknecht F D, Holmes K K 1984 Nitrocellulose filter blots for species identification of Mobiluncus curtisii and Mobiluncus mulieris. Journal of Clinical Microbiology 20:826-827.

Roberts M C, Hillier S L, Schoenknecht F D, Holmes K K 1985 Comparison of gram stain, DNA probe, and culture for the identification of species of Mobiluncus in female genital specimens. Journal of Infectious Diseases 152:74-77.

Roberts M C, Moncla B, Kenny G E 1987a Chromosomal DNA probes for the identification of Bacteroides species. Journal of General Microbiology 133 : 1423-1430.

Roberts M C, McMillan C, Coyle M B $1987 b$ Whole chromosomal DNA probes for rapid identification of Mycobacterium tuberculosis and Mycobacterium avium complex. Journal of Clinical Microbiology 25 : 1239-1243.
Singer R H, Lawrence J B, Villnave C 1986 Optimization of in situ hybridization using isotopic and non-isotopic detection methods. BioTechniques 4:230-250.

Tee W, Anderson B N, Ross B C, Dwyer B 1987 Atypical campylobacters associated with gastroenteritis. Journal of Clinical Microbiology 25 : 1248-1252.

Totten P A et al. 1985 Campylobacter cinaedi (sp. nov.) and Campylobacter fennelliae (sp. nov.): Two new Campylobacter species associated with enteric disease in homosexual men. Journal of Infectious Diseases 151 : 131-139.

Verdlov E D, Monastyrskaya G S, Guskova L I, Levithan T L, Scheichenko V I, Budowsky E I 1974 Modification of cytidine residues with a bisulfite-o-methylhydroxylamine mixture. Biochimica et Biophysica Acta 340:153-165.

Wirth D F, Pratt D M 1982 Rapid identification of Leishmania species by specific hybridization of kinetoplast DNA in cutaneous lesions. Proceedings of the National Academy of Sciences of the USA 79:6999-7003.

Wyatt J I, Rathbone B J, Heatley R V 1986 Local immune response to gastric Campylobacter in non-ulcer dyspepsia. Journal of Clinical Pathology 39:863-870.

Zwadyk P, Cooksey R C, Thornsberry C 1986 Commercial detection methods for biotinylated gene probes: Comparison with ${ }^{32} \mathrm{P}$-labelled DNA probes. Current Microbiology 14:95-100. 